\title{
In vitro evaluation of human dental enamel surface roughness bleached with $35 \%$ carbamide peroxide and submitted to abrasive dentifrice brushing
}

\section{Avaliação in vitro da rugosidade superficial do esmalte dental humano clareado com peróxido de carbamida a $35 \%$ e submetido à escovação com dentifrícios abrasivos}

Claudia Cia Worschech*

José Augusto Rodrigues*

Luis Roberto Marcondes Martins**

Gláucia Maria Bovi Ambrosano***

\begin{abstract}
The aim of this in vitro study was to evaluate the surface roughness of human enamel bleached with $35 \%$ carbamide peroxide at different times and submitted to different superficial cleaning treatments: G1 - not brushed; G2 - brushed with fluoride abrasive dentifrice; G3 - brushed with a non-fluoride abrasive dentifrice; G4 - brushed without dentifrice. Sixty fragments of human molar teeth with 4 x $4 \mathrm{~mm}$ were obtained using a diamond disc. The specimens were polished with sandpaper and abrasive pastes. A perfilometer was used to measure roughness average (Ra) values of the initial surface roughness and at each 7-day-interval after the beginning of treatment. The bleaching was performed on the surface of the fragments for 1 hour a week, and the surface cleaning treatment for 3 minutes daily. The samples were stored in individual receptacles with artificial saliva. Analysis of variance and the Tukey test revealed significant differences in surface roughness values for G2 and G3, which showed an increase in roughness over time; G1 and G4 showed no significant roughness differences. The bleaching with $35 \%$ carbamide peroxide did not alter the enamel surface roughness, but when the bleaching treatment was performed combined with brushing with abrasive dentifrices, there was a significant increase in roughness values.
\end{abstract}

DESCRIPTORS: Tooth bleaching; Peroxides; Dentifrices; Toothbrushing.

RESUMO: O propósito deste estudo in vitro foi avaliar em diferentes tempos a rugosidade superficial do esmalte dental humano clareado com peróxido de carbamida a $35 \%$ e submetido a diferentes tratamentos superficiais de limpeza: G1 - não escovado; G2 - escovado com dentifrício fluoretado abrasivo; G3 - escovado com dentifrício não fluoretado abrasivo; G4 - escovado sem dentifrício. Sessenta fragmentos de molares humanos com 4 x $4 \mathrm{~mm}$ foram obtidos através do seccionamento com discos diamantados. Os espécimes foram polidos com lixas e pastas abrasivas. Um perfilômetro foi utilizado para determinar os valores da média de dureza Ra ("roughness average") iniciais e a cada intervalo de 7 dias após o início do tratamento clareador. O clareamento foi realizado na superficie dos fragmentos por 1 hora semanalmente, e os tratamentos superficiais, por 3 minutos diariamente. No restante do tempo, os espécimes eram armazenados em receptáculos individuais com saliva artificial. A análise de variância e o teste de Tukey revelaram diferenças estatísticas significantes na rugosidade superficial em função do tempo. G2 e G3 demonstraram um aumento nos valores de rugosidade; G1 e G4 não apresentaram diferenças estatísticas. O clareamento com peróxido de carbamida a 35\% não altera a rugosidade superficial do esmalte humano, mas, quando associado ao tratamento superficial com abrasivos, ocorre um aumento significante da rugosidade superficial.

DESCRITORES: Clareamento de dente; Peróxidos; Dentifrícios; Escovação dentária.

\section{INTRODUCTION}

Bleaching procedures have gained popularity with patients and dentists as conservative techniques to lighten natural teeth in order to improve the harmony of the smile. In-offic vital bleaching has been used to introduce the patient to the bleaching process, to improve post-bleaching cases or to function solely as a bleaching treatment ${ }^{8}$. This technique uses carbamide perox-

\footnotetext{
*MS, Department of Restorative Dentistry; **ScD, Professor, Department of Statistics; ***PhD, Professor, Department of Community Dentistry - School of Dentistry of Piracicaba, State University of Campinas.
} 
Worschech CC, Rodrigues JA, Martins LRM, Ambrosano GMB. In vitro evaluation of human dental enamel surface roughness bleached with 35\% carbamide peroxide and submitted to abrasive dentifrice brushing. Pesqui Odontol Bras 2003;17(4):342-8.

ide or hydrogen peroxide in concentrations higher than those used for at-home bleaching, and is carried out with rubber dam for 1 to 2 hours $^{8}$.

However, the exposure of tooth hard tissues to bleaching agents can result in microstructural changes in the enamel surface $e^{2,3,8,13,18}$. Some authors, through scanning electron microscopy (SEM) evaluation, have demonstrated demineralization, surface defects, and degradation of sound enamel $^{3,8,13,18}$. Fluoride therapy is strongly indicated to avoid these side effects ${ }^{1}$, and one of the most useful methods of fluoride application is the use of dentifrices.

On the other hand, abrasives dentifrices play an important role in the cleaning process by removing extrinsic stains, and patients commonly use them during the bleaching treatment. Some complicating factors may be explained by acknowledging that cleaning effectiveness may not be solely related to abrasion, and there is concern that some abrasives may contribute to excessive tooth wear ${ }^{7,11}$.

The alteration of the external enamel structure after bleaching treatment may be worse after cleaning with abrasive dentifrices as they might remove the degraded enamel an enhance the phenomena of erosion and wear.

However, to maintain oral health, teeth need to be daily brushed and there is a lack of evidence on the effects of bleaching agents combined with tooth brushing on the enamel surface as well as on its influence on enamel roughness. The goal of this study was to investigate the in vitro effects induced by an in-office bleaching regimen combined with a brushing treatment with abrasive dentifrices, with and without fluoride, on the enamel surface roughness.

\section{MATERIAL AND METHOD Experimental design}

The factors under study were cleaning surface treatment in four levels: G1 - not brushed; G2 brushed with fluoride abrasive dentifrice; G3 brushed with abrasive dentifrice without fluoride; G4 - brushed without dentifrice; and time in nine levels: baseline, $7,14,21,28$ days of bleaching treatment and $7,14,21$, and 28 days after the end of bleaching (post-treatment period).

The experimental units were 60 sound human enamel fragments, randomly assigned to treatment groups $(n=15)$. Six repeated measurements of surface roughness in roughness average $(\mathrm{Ra})$ values were recorded on the surface of every specimen at each 7-day interval (Figure 1).

\section{Enamel fragment preparation}

Since this study was designed to use human teeth, it was submitted to the Ethical Committee in Research, Piracicaba Dentistry School, State University of Campinas (UNICAMP) and it was approved in compliance with resolution CNS \#196/96 of the National Committee of Health, Health Department (Brazil).

Thirty freshly extracted human non-erupted third molars were used. Immediately after extraction, the teeth were stored in a $1 \%$ thymol solution $(\mathrm{pH}=7)$. The roots were discarded and the crowns were longitudinally sectioned with double-faced diamond disks (KG Sorensen, Barueri, SP, Brazil) using a low-speed handpiece (Kavo do Brasil, Joinville, SC, Brazil) to produce 60 enamel fragments with $4 \times 4 \mathrm{~mm}$ from the middle of the buccal or lingual aspect. The fragments presenting stains or cracks were not used. After completing the sectioning, the specimens were soaked in distilled and deionized water at $37^{\circ} \mathrm{C}$.

The enamel fragments were embedded individually in a self-curing polyestyrene resin (BL 41110, Cromex, São Paulo, SP, Brazil) in a polyvinyl chloride ring mold with $2.0 \mathrm{~cm}$ in diameter, allowing the external surface of the enamel to be exposed.

The molds were removed, and in order to shape a plane enamel surface for roughness testing, the fragments' surfaces were leveled with a water-cooling mechanical grinder (Maxgrind/Solotest, São Paulo, SP, Brazil). Aluminum oxide disks were used in a sequential granulation of 400,600 , and 1,000 (Carborundum, 3M do Brasil, Sumaré, Brazil), and, after that, the specimens were polished with felt cloth and abrasive pastes with granulation of $6,3,1$, and $1 / 2 \mu \mathrm{m}$ mixed with a mineral oil coolant (Arotec Ind. e Com. Ltda., São Paulo, Brazil).

On the specimens, a $13 \mathrm{~mm}^{2}$ circular area of enamel was standardized for treatment with the bleaching agent. Circular adhesive papers were positioned on the enamel surface and the specimens were covered with two coats of nail varnish (Colorama, CEIL, São Paulo, Brazil), and after its cure, the adhesive papers were removed. The specimens were randomly assigned to 4 groups and the baseline values of surface roughness were obtained. 
Worschech CC, Rodrigues JA, Martins LRM, Ambrosano GMB. In vitro evaluation of human dental enamel surface roughness bleached with 35\% carbamide peroxide and submitted to abrasive dentifrice brushing. Pesqui Odontol Bras 2003;17(4):342-8.

\section{Bleaching treatment}

A 35\% carbamide peroxide bleaching agent (Opalescence Quick, Ultradent Co., South Jordan, UT, USA) was selected. The enamel fragments were exposed to the bleaching agent for one hour a week, during a 28-day period.

For the bleaching agent treatment, a graduated syringe was used to apply $0.02 \mathrm{ml}$ of bleaching agent on the enamel surface of each specimen $^{6,12,15}$ at $37^{\circ} \mathrm{C}$.

After 1 hour of exposure, the bleaching agent was washed out under running distilled and deionized water for 5 seconds. Then the specimens received the surface cleaning treatment and were placed in a freshly prepared remineralization solution that was changed daily. The remineralization solution was similar to natural saliva in terms of $\mathrm{Ca}$ and $\mathrm{P}$ contents, as proposed by Featherstone et al. ${ }^{5}$ (1986) and modified by Serra and Cury in $1992^{16}$, and was composed of $1.5 \mathrm{mmol} / \mathrm{L}$ of $\mathrm{Ca}$, $50 \mathrm{mmol} / \mathrm{L}$ of $\mathrm{KCl}, 0.9 \mathrm{mmol} / \mathrm{L}$ of $\mathrm{PO}_{4}$, and $20 \mathrm{mmol} / \mathrm{L}$ of tri-hydroxymethil-aminomathan at $\mathrm{pH}=7.0$.

After 28 days, at the end of the bleaching treatment (4 applications), all groups were kept in a daily changed remineralization solution over 28 days still receiving the surface cleaning treatments.

\section{Surface cleaning treatment}

Everyday, after the bleaching treatment, the specimens were submitted to a surface cleaning treatment according to each group's specifications, as follows: Group 1, control group, was not submitted to a cleaning treatment; Groups 2 and 3 received a surface cleaning treatment with a comercial dentifrice containing calcium carbonates as abrasives, respectively with fluoride and without fluoride (Table 1); Group 4 received the brushing treatment without dentifrice.

Brushing procedures were performed for $3 \mathrm{~min}-$ utes in a brushing machine, set at a usual brush force of $200 \mathrm{~g}$ and 250 cycles per minute. The brush heads were from the same brand of nylon multi-tufted toothbrushes, and each product was brushed onto specimens with individual brush heads.

The dentifrices were freshly prepared in slurries (1 part of dentifrice to 3 parts of deionized and distilled water, in weight). The slurries were agitated for 20 minutes before use.

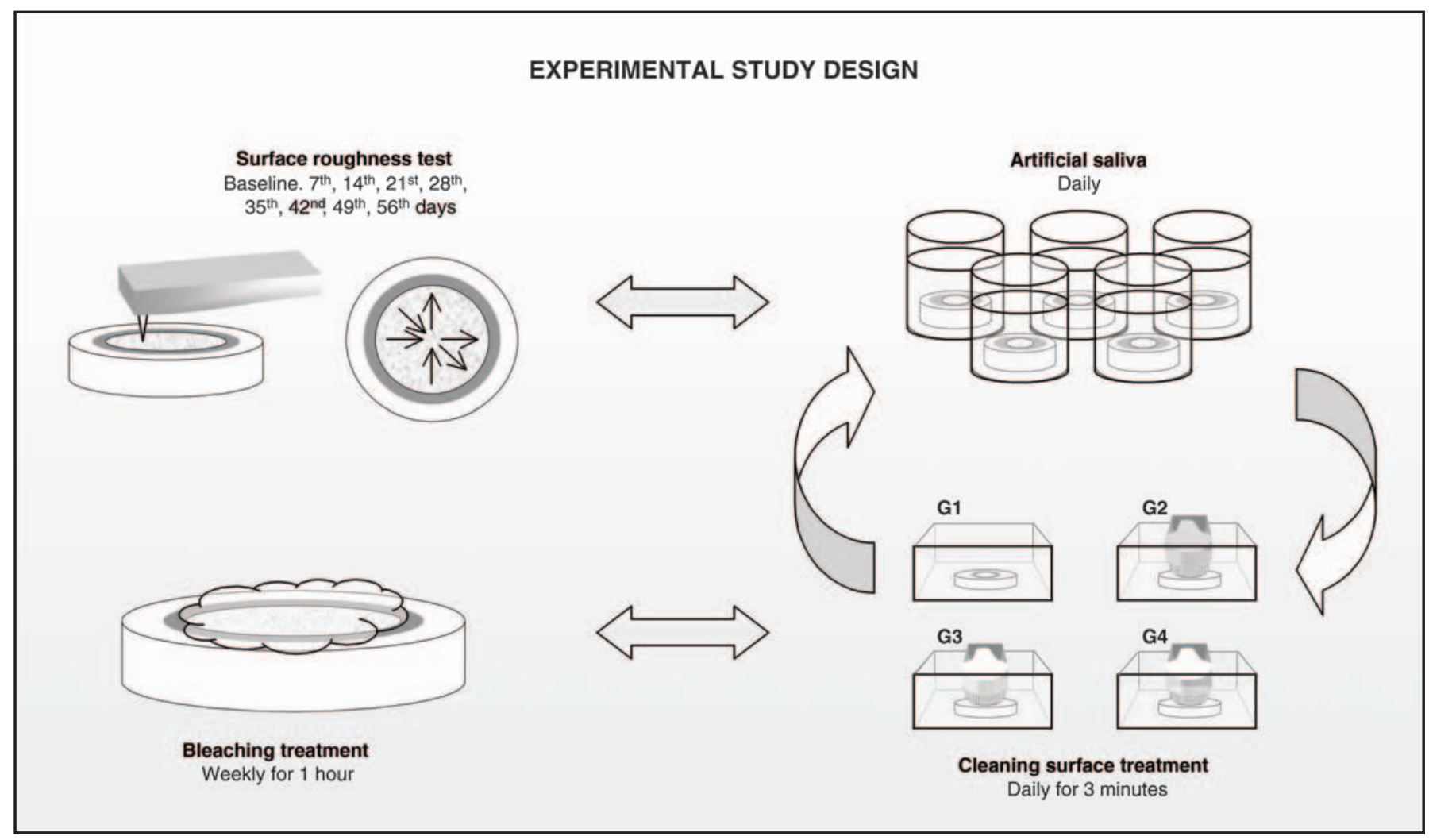

FIGURE 1 - Experimental design of the study. 
Worschech CC, Rodrigues JA, Martins LRM, Ambrosano GMB. In vitro evaluation of human dental enamel surface roughness bleached with 35\% carbamide peroxide and submitted to abrasive dentifrice brushing. Pesqui Odontol Bras 2003;17(4):342-8.

At the end of the surface cleaning treatment, the samples were removed from the machine's recipients, washed out with distilled water and maintained in individual receptacles at $37^{\circ} \mathrm{C}$ until the next brushing cycle.

\section{Surface roughness test}

Before the bleaching treatments, a perfilometer (Surf-Corder mod. 1700, Kosaka, Tokio, Japan) was used to measure the initial surface roughness (baseline). Three different directions were used to perform six measurements on the surface of each specimen, with a cut off $(\lambda c)$ of $0.25 \mathrm{~mm}$ at a veloc-

TABLE 1 - Ingredients used to prepare the dentifrices by the Proderma Pharmacy.

\begin{tabular}{l|c|c}
\hline \hline \multicolumn{1}{c|}{ Compounds } & $\begin{array}{c}\text { Abrasive } \\
\text { dentifrice with } \\
\text { fluoride (G2) }\end{array}$ & $\begin{array}{c}\text { Abrasive } \\
\text { dentifrice } \\
\text { without } \\
\text { fluoride (G3) }\end{array}$ \\
\hline $\begin{array}{l}\text { Micronized } \\
\text { calcium carbonate }\end{array}$ & $52.5 \%$ & $52.5 \%$ \\
\hline Glycerin & $25 \%$ & $25 \%$ \\
\hline Natrosol gel & $18 \%$ & $18 \%$ \\
\hline $\begin{array}{l}\text { Sodium lauryl } \\
\text { sulfate }\end{array}$ & $2 \%$ & $2 \%$ \\
\hline Sodium fluoride & $0.16 \%$ & - \\
\hline Distilled water & $\mathrm{qsp}$ & $\mathrm{qsp}$ \\
\hline \hline
\end{tabular}

ity of $0.1 \mathrm{~mm} / \mathrm{s}$ (ISO 4228). The mean $\mathrm{Ra}$ value $(\mu \mathrm{m})$ was determined for each specimen, at each 7 -day interval.

\section{RESULTS}

Statistical analysis involved a parametric method using repeated measures analysis of variance (ANOVA) followed by Tukey's HSD hoc analysis $(\alpha=0.05)$. The mean values of roughness are shown in Table 2, and the behavior of enamel roughness may be observed in Graph 1.

Baseline data were obtained in order to verify the initial surface smoothness $(\mathrm{p}<0.05)$ and to contrast differences between the groups. At the baseline values and at the $7^{\text {th }}$ day all groups showed statistically similar means. The groups submitted to surface cleaning treatments presented a statistically significant increase in the surface roughness with time, as compared to the control group (G1), that showed statistically similar means of surface roughness at different time intervals.

Group 2 showed a statistically significant increase in surface roughness from the baseline to the $14^{\text {th }}$ day and from the $14^{\text {th }}$ day to the $21^{\text {st }}$ day. After the $21^{\text {st }}$ day the values were statistically similar until the end of the treatment, with the exception of the $42^{\text {nd }}$ day, which showed the highest median value.

TABLE 2 - Means of surface roughness (Ra) and standard deviation (SD) values for each treatment agent at different time intervals.

\begin{tabular}{|c|c|c|c|c|c|c|c|c|}
\hline \multirow[b]{3}{*}{ Period } & \multicolumn{8}{|c|}{ Groups } \\
\hline & \multicolumn{2}{|c|}{ G1 - non brushed } & \multicolumn{2}{|c|}{$\begin{array}{c}\text { G2 - brushed with } \\
\text { fluoride abrasive } \\
\text { dentifrice }\end{array}$} & \multicolumn{2}{|c|}{$\begin{array}{l}\text { G3 - brushed with } \\
\text { abrasive dentifrice }\end{array}$} & \multicolumn{2}{|c|}{$\begin{array}{c}\text { G4 - brushed without } \\
\text { dentifrice }\end{array}$} \\
\hline & Means & SD & Means & SD & Means & $\mathrm{SD}$ & Means & $\mathrm{SD}$ \\
\hline Baseline & $0.089 \mathrm{~A} \mathrm{a}$ & 0.033 & $0.100 \mathrm{~A} \mathrm{~d}$ & 0.031 & $0.085 \mathrm{~A} \mathrm{~d}$ & 0.031 & $0.096 \mathrm{~A} \mathrm{c}$ & 0.027 \\
\hline $7^{\text {th }}$ day & $0.096 \mathrm{~A} \mathrm{a}$ & 0.037 & $0.125 \mathrm{~A} \mathrm{~cd}$ & 0.030 & $0.116 \mathrm{Ac}$ & 0.031 & $0.094 \mathrm{~A} \mathrm{c}$ & 0.029 \\
\hline $14^{\text {th }}$ day & $0.098 \mathrm{~B} \mathrm{a}$ & 0.035 & $0.148 \mathrm{~A} \mathrm{c}$ & 0.045 & $0.138 \mathrm{AB} \mathrm{c}$ & 0.052 & $0.101 \mathrm{AB} b \mathrm{~b}$ & 0.021 \\
\hline $21^{\text {st }}$ day & $0.101 \mathrm{~B} \mathrm{a}$ & 0.037 & $0.177 \mathrm{~A} \mathrm{~b}$ & 0.053 & $0.176 \mathrm{~A} \mathrm{~b}$ & 0.063 & $0.114 \mathrm{~B} \mathrm{abc}$ & 0.032 \\
\hline $28^{\text {th }}$ day & $0.107 \mathrm{~B} \mathrm{a}$ & 0.038 & $0.176 \mathrm{~A} \mathrm{~b}$ & 0.064 & $0.185 \mathrm{~A} \mathrm{ab}$ & 0.082 & $0.108 \mathrm{~B} \mathrm{abc}$ & 0.033 \\
\hline $35^{\text {th }}$ day & $0.105 \mathrm{~B} \mathrm{a}$ & 0.033 & $0.201 \mathrm{~A} \mathrm{ab}$ & 0.074 & $0.190 \mathrm{~A} \mathrm{ab}$ & 0.074 & $0.129 \mathrm{~B} \mathrm{a}$ & 0.039 \\
\hline $42^{\text {nd }}$ day & $0.109 \mathrm{~B} \mathrm{a}$ & 0.040 & $0.203 \mathrm{~A} \mathrm{a}$ & 0.067 & $0.203 \mathrm{~A} \mathrm{a}$ & 0.087 & $0.122 \mathrm{~B} \mathrm{ab}$ & 0.031 \\
\hline $49^{\text {th }}$ day & $0.108 \mathrm{~B} \mathrm{a}$ & 0.044 & $0.198 \mathrm{~A} \mathrm{ab}$ & 0.053 & $0.188 \mathrm{~A} \mathrm{ab}$ & 0.081 & $0.120 \mathrm{~B}$ abc & 0.044 \\
\hline $56^{\text {th }}$ day & $0.111 \mathrm{~B} \mathrm{a}$ & 0.051 & $0.190 \mathrm{~A} \mathrm{ab}$ & 0.054 & $0.187 \mathrm{~A} \mathrm{ab}$ & 0.067 & $0.119 \mathrm{~B}$ abc & 0.041 \\
\hline
\end{tabular}

The Tukey test compared differences between time intervals at the $5 \%$ level of significance $(\mathrm{p}<0.05)$. Same letters indicate mean values that are not significantly different; capital letters are considered in the horizontal direction and lowercase letters are considered in the vertical direction. 
Worschech CC, Rodrigues JA, Martins LRM, Ambrosano GMB. In vitro evaluation of human dental enamel surface roughness bleached with 35\% carbamide peroxide and submitted to abrasive dentifrice brushing. Pesqui Odontol Bras 2003;17(4):342-8.

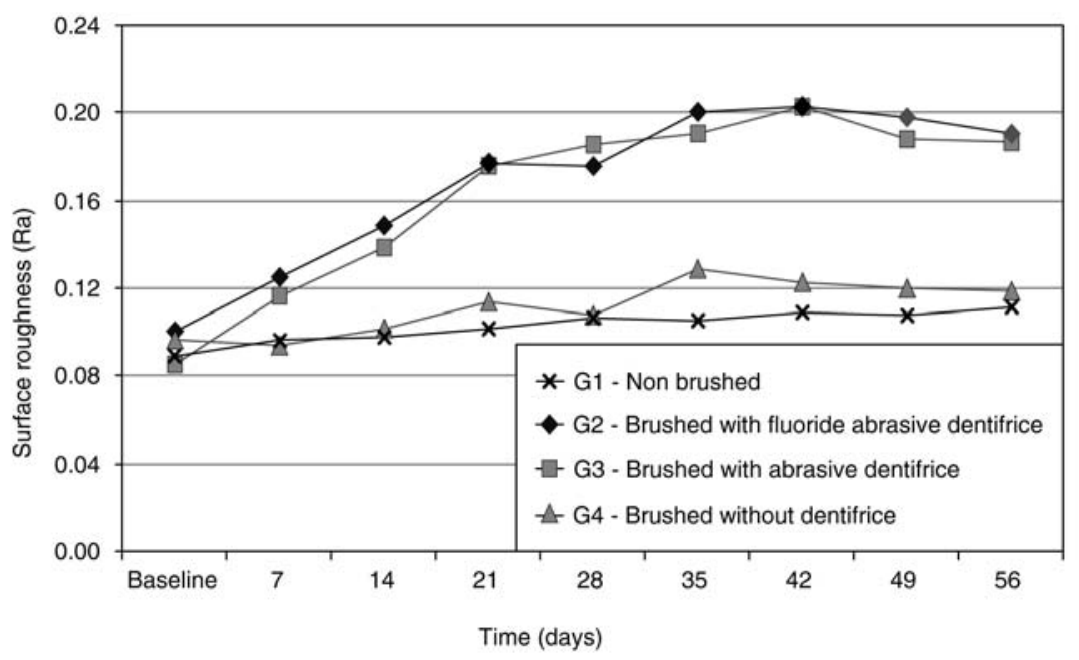

GRAPH 1 - Mean roughness of enamel fragments bleached and submitted to superficial cleaning treatment at different time intervals.

The mean values of roughness in Group 3 showed a statistical increase from baseline to the $7^{\text {th }}$ and $14^{\text {th }}$ days which were not different from each other. At the $21^{\text {st }}$ day the roughness mean values increased and were statistically different from the baseline, $7^{\text {th }}$ and $14^{\text {th }}$ day values. At the $28^{\text {th }}$ day the roughness presented an increase until the $42^{\text {nd }}$ day, which differed statistically from that of the $21^{\text {st }}$ day, and the roughness values showed a decrease but the values did not differ statistically from the $28^{\text {th }}$ day until the $56^{\text {th }}$ day.

Group 4 showed statistically similar roughness values until the $28^{\text {th }}$ day. The $35^{\text {th }}$ day showed the highest roughness median value of this group, which statistically differed from those of the baseline, $7^{\text {th }}$, and $14^{\text {th }}$ days. After the $35^{\text {th }}$ day, these values decreased, and the value of the $42^{\text {nd }}$ day statistically differed from those of the baseline and $7^{\text {th }}$ day. The values of the $49^{\text {th }}$ and $56^{\text {th }}$ days did not differ from all the values and also from the baseline values.

\section{DISCUSSION}

Patients who submit themselves to a tooth bleaching treatment generally are patients that brush their teeth 3 or 4 times a day to achieve health and beauty. Dentifrices are sometimes recommended for specific purposes, like cleaning or abrasion, in order to improve the bleaching process by removing superficial stains and polishing teeth. The most common abrasives these days are hydrated silica, dicalcium phosphate dihydrate, and calcium carbonate ${ }^{21}$. However, their abrasiveness may be responsible for superficial tooth wear and other complicating factors ${ }^{11}$, and abrasion may be more severe when associated to bleaching treatment regimens.

Several studies have evaluated the effects of bleaching agents on tooth structure mainly using scanning electron microscopy. The use of $10 \%$ carbamide peroxide has produced slight surface modifications and the use of highly concentrated agents indicated for in-office treatment has caused more severe alterations on the enamel microstructure ${ }^{10,13,24}$. The microhardness in vitro studies have demonstrated contradictory results, presenting mineral loss with the extended use of low $\mathrm{pH}$ agents, or increase in the mineral content due to demineralization and remineralization phenomena caused by the use of remineralization solutions and agents with neutral $\mathrm{pH}^{1,15}$.

Profilometric analyses are also conflicting. Titley et $a .^{20}$ (1988) found an apparent increase in surface porosities on enamel after the use of a $35 \%$ solution of hydrogen peroxide; McGuckin et al. ${ }^{13}$ (1992) observed a slight increase in surface roughness after the use of $30 \%$ hydrogen peroxide, whereas Wandera et $a l_{.}{ }^{22}$ (1994) and Gürgan et al. ${ }^{9}$ (1997) reported no surface alterations after bleaching with at-home agents as observed in the present study in G1.

However, the protocol employed in this study tried to be similar to an in-office bleaching treatment performed in the oral cavity with the bleach- 
Worschech CC, Rodrigues JA, Martins LRM, Ambrosano GMB. In vitro evaluation of human dental enamel surface roughness bleached with 35\% carbamide peroxide and submitted to abrasive dentifrice brushing. Pesqui Odontol Bras 2003;17(4):342-8.

ing agent application followed by brushing and immersion in a solution similar to artificial saliva. The use of artificial saliva may decrease superficial erosion and it might favor remineralization of the enamel surface ${ }^{17}$, a possible reason for the results observed in G1. Nevertheless, the sole use of 35\% carbamide peroxide for 1 hour weekly did not cause surface roughness alterations.

The aim of this study was to evaluate in vitro the effect of in-office bleaching associated to abrasive dentifrices brushing. G1 may be considered a control group because it was not brushed and did not show alterations in enamel roughness during the experimental treatment times. G4 was a second control group whose specimens were not brushed with abrasive dentifrices and did not differ statistically from G1, demonstrating that the brushing had no effect on the bleached enamel surface roughness. However, the roughness tests were performed in the samples before and during experimental times, so that each specimen in a group could be considered as its own control. G4 had a non-statistical increase from baseline to the $28^{\text {th }}$ day, which was statistically significant at the $35^{\text {th }}$ day, suggesting a slight effect of the brushing during the bleaching treatment; however, such effect was not significant at the $49^{\text {th }}$ and $56^{\text {th }}$ days.

The enamel surface roughness was increased after the surface cleaning treatment with abrasive dentifrices in G2 and G3. Although the roughness of these groups had been similar during all experiment times, the increase occurred from the $14^{\text {th }}$ day, for G2, and from the $21^{\text {st }}$ day, for G3, up to the $42^{\text {nd }}$ day; after that day the roughness kept high until the $56^{\text {th }}$ day, revealing higher roughness values than the baseline ones, G1, and G4.

Our results indicate that the fluoride present in G2 was not able to prevent the increase in the surface roughness, and it may be supposed that some erosion and loss of enamel had occurred. Attin et $a l .{ }^{1}$ (1997) have shown that the application of a fluoride solution cannot prevent, but may reduce, the loss of mineral from enamel during at-home bleaching treatment with $10 \%$ carbamide peroxide. According to Neves et al. ${ }^{14}$ (2002) the appearances of enamel surfaces brushed with either a fluoridated or non-fluoridated dentifrice were quite similar. The same study showed that the control group, brushed with toothbrush and water, showed a smooth surface caused by the tooth brushing treatment.

Nevertheless, the G4 roughness values were statistically similar to those of G1 (control group) at all the studied times; G4 presented a surface roughness that ranked between the groups brushed with abrasive dentifrices (G2 and G3) and the control group (G1), strengthening the possible erosive effect of the brushing without the dentifrices.

On the other hand, this study evaluated only one surface roughness parameter, the $\mathrm{Ra}$. This parameter describes the overall roughness of a surface and it can be defined as the arithmetic average value of all absolute distances of the roughness profile from the centerline within the measuring length. Although the $\mathrm{Ra}$ parameter is the most used parameter to evaluate roughness, other parameters may be used as complementary data to obtain more information about the profile shape ${ }^{23}$.

This study has been one of the first to evaluate the effects of abrasive dentifrices on enamel roughness after in-office bleaching and adverse effects were observed. Further research using other roughness parameters and in vitro and in vivo models are necessary to observe these adverse effects on the enamel surface.

The oxidative process involved in and the low $\mathrm{pH}$ of tooth-bleaching products have been considered as the main source of adverse effects on mineralized tissues during bleaching treatments ${ }^{15}$. Low concentrations of carbamide peroxide promote varying degrees of surface porosity and structural change, depending on the bleaching agent $t^{4,10,13,24}$. The use of abrasive-containing dentifrice might result in enamel microwear ${ }^{14,21}$. The slight abrasion in this enamel may remove the superficial degraded layer and promote a "new" surface, even though, with high roughness values ${ }^{14}$.

The bleached enamel surfaces treated with abrasive dentifrices with or without fluoride were markedly altered in our study. In spite of these results, the use of rational and daily fluoride therapy, specially mouth rinsing with fluoride and neutral solutions, associated with fluoride dentifrices without abrasives is an important method to prevent a possible erosion caused on the enamel due to the use of superficial cleaning treatments after bleaching agents ${ }^{19}$. 
Worschech CC, Rodrigues JA, Martins LRM, Ambrosano GMB. In vitro evaluation of human dental enamel surface roughness bleached with 35\% carbamide peroxide and submitted to abrasive dentifrice brushing. Pesqui Odontol Bras 2003;17(4):342-8.

\section{CONCLUSION}

This in vitro investigation showed that $35 \%$ carbamide peroxide did not alter enamel surface roughness, but when the bleaching treatment was

\section{REFERENCES}

1. Attin T, Kielbassa AM, Schwanenberg M, Hellwig E. Effect of fluoride treatment on remineralization of bleached enamel. J Oral Rehabil 1997;24:282-6.

2. Basting RT, Rodrigues AL, Serra MC. The effect of $10 \%$ carbamide peroxide bleaching material on microhardness of sound and demineralized enamel and dentin in situ. Oper Dent 2001;26:531-9.

3. Bitter NC. A scanning electron microscopy study of the effect of bleaching agents on enamel: a preliminary report. J Prosthet Dent 1992;67:852-5.

4. Ernest CP, Marroquin BB, Willershausen-Zönnchen B. Effects of hydrogen peroxide-containing bleaching agents on the morphology of human enamel. Quintessence Int 1996;27:53-6.

5. Featherstone JDB, O'Really MM, Shariati M, Brugler S. Enhancement of remineralization in vitro and in vivo. In: Leach SA. Factors relating to demineralization and remineralization of the teeth. $3^{\text {rd }}$ ed. Oxford: IRL; 1986. p. 23-34.

6. Freitas PM, Basting RT, Rodrigues AL, Serra MC. Effects of two $10 \%$ peroxide carbamide bleaching agents on dentin microhardness at different time intervals. Quintessence Int 2002;33:370-5.

7. Gerlach RW, Barker ML, Hyde JD, Jones MB. Effects of a tartar control whitening dentifrice on tooth shade in a population with long-standing natural stain. J Clin Dent 2001;12:47-50.

8. Gultz J, Kaim J, Scherer W, Gupta H. Two in-office bleaching systems: a scanning electron microscope study. Compend Contin Educ Dent 1999;20:965-70.

9. Gürgan S, Bolay S, Alacan R. Adherence of bacteria to bleached or unbleached enamel surfaces. J Oral Rehabil $1997 ; 24: 624$.

10. Hegedüs C, Bistey T, Flora-Nagy E, Keszthelyi G, Jenei A. An anatomic force microscopy study on the effect of bleaching agents on enamel surface. J Dent 1999; 27:509-15.

11. Isaacs RL, Bartizek RD, Owens TS, Walters PA, Gerlach RW. Maintenance of tooth color after prophylaxis: comparison of three dentifrices. J Clin Dent 2001;12:51-5. performed with cleaning treatments, through brushing with abrasive dentifrices, a significant increase in roughness values was observed.

12. McCracken MS, Haywood VB Demineralization effects of 10 percent carbamide peroxide. J Dent 1996;24:395-8.

13. McGuckin RS, Babin JF, Meyer BJ. Alterations in human enamel surface morphology following vital bleaching. J Prosthet Dent 1992;68:754-60.

14. Neves NA, Castro RA, Coutinho ET, Primo LG. Microstructural analysis of demineralized primary enamel after in vitro tooth brushing. Pesqui Odontol Bras 2002;16:137-43.

15. Rodrigues JA, Basting RT, Rodrigues Jr AL, Serra MC. Effects of $10 \%$ carbamide peroxide bleaching materials on enamel microhardness. Am J Dent 2001;14:67-71.

16. Serra MC, Cury JA. The in vitro effect of glass-ionomer cement restoration on enamel subjected to a demineralization and remineralization model. Quintessence Int 1992; 24:39-44.

17. Silverstone, LM. Remineralization phenomena. Caries Res 1997;11(Supp1):59-84

18. Smidt A, Weller D, Roman I. Effect of bleaching agents on microhardness and surface morphology of tooth enamel. Am J Dent 1998;11:83-5.

19. Tames D, Grando J, Tames DR. Alterações do esmalte dental submetido ao tratamento com peróxido de carbamida 10\%. Rev Assoc Paul Cir Dent 1998;52:145-9.

20. Titley K, Torneck CD, Smith D. The effect of concentrated hydrogen peroxide solutions on the surface morphology of human tooth enamel. J Endod 1988;14:69-74.

21. Viscio D, Gaffar A, Fakhry-Smity S, Xu T. Present and future technologies of tooth whitening. Compend Contin Educ Dent 2000;21:36-43.

22. Wandera A, Feigal RJ, Douglas WH, Pintado MR. Home-use tooth bleaching agents: an in vitro study on quantitative effects on enamel, dentin and cementum. Quintessence Int 1994;25:541-6.

23. Whitehead SA, Shearer AC, Watts DC, Wilson NHF. Comparison of methods for measuring surface roughness of ceramic. J Oral Rehabil 1995;22:421-7.

24. Zalking M, Arwaz JR, Goldman A, Rotstein I. Surface morphology changes in human enamel, dentin and cementum following bleaching: a scanning electron microscopy study. Endod Dent Traumatol 1996;12:82-8.

Recebido para publicação em 09/06/03 Enviado para reformulação em 10/09/03 Aceito para publicação em 04/11/03 